\title{
Ambiances
}

anbiances Environnement sensible, architecture et espace urbain Redécouvertes | 2013

\section{The art of the stage set as a paradigm for an aesthetics of atmospheres}

La scénographie comme paradigme d'une esthétique des ambiances

\section{Gernot Böhme}

\section{(2) OpenEdition}

\section{Journals}

\section{Electronic version}

URL: http://journals.openedition.org/ambiances/315

DOI: 10.4000/ambiances.315

ISSN: 2266-839X

\section{Publisher:}

Direction Générale des Patrimoines - DAPA - MCC, UMR 1563 - Ambiances Architectures Urbanités $(\mathrm{AAU})$

\section{Electronic reference}

Gernot Böhme, «The art of the stage set as a paradigm for an aesthetics of atmospheres »,

Ambiances [Online], Rediscovering, Online since 10 February 2013, connection on 22 September 2020.

URL : http://journals.openedition.org/ambiances/315; DOI : https://doi.org/10.4000/ambiances.315

This text was automatically generated on 22 September 2020 .

\section{cc) $(1) \ominus$}

Ambiances is licensed under a Creative Commons Attribution-NonCommercial-NoDerivatives 4.0 International License. 


\title{
The art of the stage set as a paradigm for an aesthetics of atmospheres
}

La scénographie comme paradigme d'une esthétique des ambiances

\author{
Gernot Böhme
}

\section{Making atmospheres}

1 Our general theme, Making atmospheres ${ }^{1}$, has a provocative character. It sounds slightly perverse, even paradoxical. Making - does that not have to do with something tangible? With the world of concrete things and apparatuses? And atmosphere - is that not something airy, indefinite, something which is simply there and comes over us? How is one supposed to make atmospheres? Well, there is one sphere in which that has actually been going on for a long time: the art of the stage set. In it we have a paradigm which not only encourages us in our enterprise but endows the idea of making atmospheres with objective reality ${ }^{2}$.

\section{Atmosphere - a familiar yet extremely vague phenomenon}

2 The term atmosphere has its origin in the meteorological field and refers to the earth's envelope of air which carries the weather. It is only since the 18th century that it has been used metaphorically, for moods which are "in the air", for the emotional tinge of a space. Today this expression is commonly used in all European languages; no longer it seems artificial and is hardly even regarded as a metaphor. One speaks of the atmosphere of a conversation, a landscape, a house, the atmosphere of a festival, an evening, a season. The way in which we speak of atmospheres in these cases is highly differentiated - even in everyday speech. An atmosphere is tense, light-hearted or 
serious, oppressive or uplifting, cold or warm. We also speak of the atmosphere of the "petite bourgeoisie", the atmosphere of the Twenties, the atmosphere of poverty. To introduce some order into these examples, atmospheres can be divided into moods, phenomena of synaesthesia, suggestions for motions, communicative and socialconventional atmospheres. What matters is that, in speaking of atmospheres, we refer to their character. With this term character we already bring our understanding of atmospheres close to the sphere of physiognomy and theatre. The character of an atmosphere is the way in which it communicates a feeling to us as participating subjects. A solemn atmosphere has the tendency to make my mood serious, a cold atmosphere causes me to shudder.

The scholarly use of the term atmosphere is relatively new. It began in the field of psychiatry, specifically in Hubert Tellenbach's book Geschmack und Atmosphäre [Taste and atmosphere] (Tellenbach, 1968). Here, atmosphere refers to something bordering on the olfactory - such as the climate of the homeland or the smell of the nest, that is, a sphere of familiarity which is perceptible in a bodily-sensuous way. Since then, atmospheres have been researched in detail by phenomenology. Talk about atmospheres plays a part today in interior design, town planning, advertising and all fields related to the art of the stage set - that is, the creation of backgrounds in radio, film and television. In general, it can be said that atmospheres are involved wherever something is being staged, wherever design is a factor - and that now means: almost everywhere.

Now, this matter-of-fact way in which atmospheres are talked about and manipulated is extremely surprising, since the phenomenon of atmosphere is itself something extremely vague, indeterminate, intangible. The reason is primarily that atmospheres are totalities: atmospheres imbue everything, they tinge the whole of the world or a view, they bathe everything in a certain light, unify a diversity of impressions in a single emotive state. And yet one cannot actually speak of "the whole", still less of the whole of the world; speech is analytical and must confine itself to particulars. Moreover, atmospheres are something like the aesthetic quality of a scene or a view, the "something more" that Adorno refers to in somewhat oracular terms in order to distinguish a work of art from a mere "piece of work"; or they are "the Open" which, since Heidegger, has given us access to the space in which something appears. Seen in this way, atmospheres have something irrational about them, in a literal sense: something inexpressible. Finally, atmospheres are something entirely subjective: in order to say what they are or, better, to define their character, one must expose oneself to them, one must experience them in terms of one's own emotional state. Without the sentient subject, they are nothing.

5 And yet: the subject experiences them as something "out there", something which can come over us, into which we are drawn, which takes possession of us like an alien power. So, are atmospheres something objective after all? The truth is that atmospheres are a typical intermediate phenomenon, something between subject and object. That makes them, as such, intangible, and means that - at least in the European cultural area - they have no secure ontological status. But for that very reason it is rewarding to approach them from two sides, from the side of subjects and from the side of objects, from the side of reception aesthetics and from the side of production aesthetics. 


\section{Reception aesthetics and production aesthetics}

6 The conception of atmospheres as a phenomenon has its origin in reception aesthetics. Atmospheres are apprehended as powers which affect the subject; they have the tendency to induce in the subject a characteristic mood. They come upon us from we know not where, as something nebulous, which in the 18th century might have been called a je ne sais quoi, they are experienced as something numinous - and therefore irrational.

7 The matter looks different if approached from the side of production aesthetics, which makes it possible to gain rational access to this "intangible" entity. It is the art of the stage set which rids atmospheres of the odour of the irrational: here, it is a question of producing atmospheres. This whole undertaking would be meaningless if atmospheres were something purely subjective. For the stage set artist must relate them to a wider audience, which can experience the atmosphere generated on the stage in, by and large, the same way. It is, after all, the purpose of the stage set to provide the atmospheric background to the action, to attune the spectators to the theatrical performance and to provide the actors with a sounding board for what they present. The art of the stage set therefore demonstrates from the side of praxis that atmospheres are something quasi-objective. What does that mean?

Atmospheres, to be sure, are not things. They do not exist as entities which remain identical over time; nevertheless, even after a temporal interruption they can be recognised as the same, through their character. Moreover, although they are always perceived only in subjective experience - as a taste or a smell, for example, to return to Tellenbach - it is possible to communicate about them intersubjectively. We can discuss with one another what kind of atmosphere prevails in a room. This teaches us that there is an intersubjectivity which is not grounded in an identical object. We are accustomed, through the predominant scientific mode of thinking, to assume that intersubjectivity is grounded in objectivity, that detection of the presence and determinateness of something is independent of subjective perception and can be delegated to an apparatus. Contrary to this, however, the quasi-objectivity of atmospheres is demonstrated by the fact that we can communicate about them in language. Of course, this communication has its preconditions : an audience which is to experience a stage set in roughly the same way must have a certain homogeneity, that is to say, a certain mode of perception must have been instilled in it through cultural socialisation.

9 Nevertheless, independently of the culture-relative character of atmospheres, their quasi-objective status is preserved. It manifests itself in the fact that atmospheres can be experienced as surprising, and, on occasions, in contrast to one's own mood. An example is when, in a cheerful mood, I enter a community in mourning : its atmosphere can transform my mood to the point of tears. For this, too, the stage set is a practical proof.

\section{Phantastike techne}

10 All the same, can one really make atmospheres? The term making refers to the manipulating of material conditions, of things, apparatus, sound and light. But 
atmosphere itself is not a thing; it is rather a floating in-between, something between things and the perceiving subjects. The making of atmospheres is therefore confined to setting the conditions in which the atmosphere appears. We refer to these conditions as generators.

11 The true character of a making, which does not really consist in producing a thing, but in making possible the appearance of a phenomenon by establishing conditions, can be clarified by going back to Plato's theory of mimesis. ${ }^{3}$

In the dialogue Sophist, Plato draws a distinction between two kinds of performing art, in order to unmask the mendacious art of the Sophists (Sophist, 235e3-236c7). There is a difference, he argues, between eikastike techne and phantastike techne. It is the latter which interests us here. In eikastike techne, mimesis consists in the strict imitation of a model. Phantastike techne, by contrast, allows itself to deviate from the model. It takes account of the viewpoint of the observer, and seeks to make manifest what it represents in such a way that the observer perceives it "correctly". Plato bases this distinction on the practice of the sculptors and architects of his time. For example, the head of a very tall statue was made relatively too large, so that it did not appear too small to the observer, or the horizontal edges of a temple were curved slightly upwards, so that they did not seem to droop to the observer (Lamb et Curtius, 1944, p.17). This art of phantastike is perhaps not yet quite what we mean by the art of making atmospheres, but it already contains the decisive feature: that the artist does not see his actual goal in the production of an object or work of art, but in the imaginative idea the observer receives through the object. That is why this art is called phantastike techne. It relates to the subject's power of representation, to the imagination or imaginatio. We come close to what concerns us through the skenographia developed by the Greeks as early as the fourth century BC. In his Poetics 1449a18 Aristotle ascribes this to the tragedian Sophocles. The classical philologists believed that skenographia already implied perspective painting, an invention frequently attributed to the Renaissance (Frank, 1962, p. 20). They claimed that the geometrical doctrine of proportion, in particular the theorem of radiation we find developed in the Elements of Euclid, was derived from skenographia. For in order to create spatial depth through painting, perspectival foreshortening of the objects represented - buildings, trees, people - is needed. In scenography, therefore, we have an art form which is now directed explicitly, in its concrete activity, towards the generation of imaginative representations in the subjects, here the audience. It does not want to shape objects, but rather to create phenomena. The manipulation of objects serves only to establish conditions in which these phenomena can emerge. But that is not achieved without the active contribution of the subject, the onlooker. It is interesting when Umberto Eco claims precisely this for all pictorial representation (Eco, 1976, p. 32, footnote 7): It does not copy the object, he asserts, but only creates the conditions of perception under which the idea of the object appears for the viewer of the image. That may be overstated, yet it is true for Impressionist painting, for example. That painting does not aim to copy an object or a landscape, but rather to awaken a particular impression, an experience in the onlooker. The most convincing proof of this is the technique of pointillism. The colours the painter wishes the onlooker to see are not located on the painted surface but "in space", or in the imagination of the onlooker.

13 Of course, the art of the stage set has by now advanced beyond pure scenography. Wagner's operas seem to have given particular impetus to this development, firstly 
because they demanded a fantastic ambiance in any case and, secondly, because they were intended to act especially on the feelings, not just the imagination (Schuberth, 1955, p. 86, p. 95). But the breakthrough came only in the 20th century, with the mastery of light and sound through electrical technology ${ }^{4}$. Here, a stage art has now been developed which is no longer confined to the design and furnishing of the stage space but, on the one hand, causes the action on the stage to appear in a particular light and, on the other, creates an acoustic space which tunes the whole performance. At the same time, this has made it possible for the art of the stage set to leave the stage itself and spill over into the auditorium, or even into space itself. The spaces generated by light and sound are no longer something perceived at a distance, but something within which one is enclosed. This has also enabled the art of the stage set to expand into the general art of staging, which has applications, for example, in the decor of discotheques and the design of large-scale events such as open-air festivals, opening ceremonies of sports events, etc. (Larmann, 2007).

The present dominance of light and sound design also enables us to discern in retrospect what the making of atmospheres consists of in the more object-related field. It becomes clear that what is at issue is not really visual spectacles - as was perhaps believed by practitioners of the old scenography - but the creation of "tuned" spaces, that is to say, atmospheres. The making, as long as it concerns a shaping and establishing of the geometrical space and its contents, cannot therefore relate to the concrete qualities possessed by the space and the things within it. Or, more precisely: it does not relate to the determinations of things, but to the way in which they radiate outwards into space, to their output as generators of atmospheres. Instead of properties, therefore, I speak of ekstases ${ }^{5}$ - that is, ways of stepping-outside-oneself. The difference between properties and ekstases can be clarified by the antithesis between convex and concave: a surface which, in relation to the body it encloses, is convex, is concave in relation to the surrounding space.

We are concerned, therefore, with ekstases, with the expressive forms of things. We are not accustomed to characterising things in terms of their ekstases, although they are crucial to design, for example. In keeping with our ontological tradition, we characterise things in terms of their material and their form. For our present purpose, however, the thing-model of Jacob Böhme is far more appropriate. He conceives of things on the model of a musical instrument (Böhme, 1922). In these terms, the body is something like the sounding board of a musical instrument, while its outward properties, which Böhme calls "signatures", are moods which articulate its expressive forms. And finally, what is characteristic of things is their tone, their "odour" or emanation - that is to say, the way in which they express their essence.

Tone and emanation - in my terminology, ekstases - determine the atmosphere radiated by things. They are therefore the way in which things are felt present in space. This gives us a further definition of atmosphere: it is the felt presence of something or someone in space. For this the ancients had the beautiful expression parousia. Thus, for Aristotle, light is the parousia of fire (De anima, 22b17.).

\section{Conclusion}

17 What I, harking back to Plato, called phantastike techne, would no doubt today be called design. We have oriented ourselves here by a prototypical area of design: stage design. 
But for our purpose it is important to modify the traditional understanding of design, according to which design amounted merely to shaping or configuring. That understanding is already prohibited by the extraordinary importance of light and sound, not only in the field of the stage set but also in advertising, marketing, town planning, interior design. One might speak of a practical, or better: a poetic phenomenology, because we are dealing here with the art of bringing something to appearance. A term used by the phenomenologist Hermann Schmitz is very apt here: he speaks of a "technology of impression" [Eindruckstechnik] (Schmitz, 1999). Admittedly, this term is used polemically, being applied to the generation of impressions for propaganda purposes in the Nazi period, or what Walter Benjamin called the "aestheticizing of political life" (Benjamin, 2003, p. 269). Let us therefore speak more generally of the art of staging. On the one hand, then, we have preserved the connection to our paradigm of the art of the stage set and, on the other, we have included in this expression the purpose for which atmospheres are predominantly generated today: the stage set is itself a part of the staging of a drama or opera. The art of atmospheres, as far as it is used in the production of open-air festivals or in the build-up to large sporting events such as the Football World Cup or the Olympic Games, is their staging. The role of the generation of atmospheres in marketing is that of staging commodities. The commodities themselves are valued, in the aesthetic economy where they now serve only relatively little to satisfy basic needs, for their staging-value, that is, they are valued to the extent that they help individuals or groups to stage their own lifestyles. And finally, in democracies, or more precisely media-democracies, in which politics is performed as if in a theatre, the generation of atmospheres has the function of staging personalities or political events.

If we review these examples, it emerges that the attention which is now paid to atmospheres in aesthetic theory has its material background in the fact that staging has become a basic feature of our society: the staging of politics, of sporting events, of cities, of commodities, of personalities, of ourselves. The choice of the paradigm of the stage set for the art of generating atmospheres therefore mirrors the real theatricalisation of our life. This is why the paradigm stage set can teach us so much, in theoretical terms, about the general question of the generation of atmospheres, and therefore about the art of staging. But in practical terms, too, there ought to be much to be learned from the great tradition of stage set design. That will happen indeed, but one should not expect that it will be possible to say very much about it. For the art of the stage set has been transmitted up to now, like traditional crafts, in master-pupil relationships, by collaboration and imitation. The guiding practical knowledge is tacit knowledge. It is all the more pleasing to find now and then, in the many books which exist on the subject of the stage set, something explicit about the craft. In conclusion, I will give an example of such knowledge from the praxis of the stage set. It is found in, of all places, a philosophical dissertation, Robert Kümmerlen's book Zur Aesthetik bühnenräumlicher Prinzipien (Kümmerlen, 1929).

Kümmerlen writes about the use of light on the stage. He argues, we should note, that an atmosphere is created on the stage with light. He then defines the effect of the lightatmosphere more precisely by saying that a characteristic mood is imparted by it to the performance. As examples, he mentions somber and charming moods - that is, moods with a synaesthetic and a communicative character. Finally, he also recognises the status of the "in-between existence" typical of atmospheres: "The lighting on its own 
generates a fluid between the individual structures of the performance". But now, let me give the quotation in full:

The space to be contemplated is given its brightness by the lighting; stage performances are only made visible by light. The first function of lighting, the simple provision of light, creates, with the brightness, what might be called the atmosphere in which the space exists. The light-atmosphere, achieved in the most diverse ways, varies the space; through the lighting the performances take on a characteristic mood. The space creates an effect in its totality; the lights of the special representation produce a self-contained impression; the space stands in a unifying light. With the illumination of the whole scene a "unified character" is produced. A uniform mood emanates from the space; for example, the representation of space is subjected to a "muted" light. We find that threedimensional objects "gleam" in a regular light; the space appears, for example, as "charming" or "somber". The lighting on its own generates a fluid between the individual structures of the performance. A specific mood is contained in the space represented through the ethereal effect of brightness (Kümmerlen, 1929, p. 36).

\section{BIBLIOGRAPHY}

Benjamin, Walter. 2003. The Work of Art in the Age of its Technical Reproducibility [translated by Edmund Jephcott]. In: Walter. Benjamin. Selected Writings, vol. 4, Cambridge Mass. and London: Harvard University Press. p. 19-55

Böhme, Gernot. 2011. Un paradigme pour une esthétique des ambiances : l'art de la scénographie. In : Augoyard, Jean-François (ed.). Faire une ambiance = creating an atmosphere : actes du colloque international Grenoble 10-12 septembre 2008. Grenoble : A la croisée. p. 221-228

Böhme, Gernot. 2001/2005. Aisthetik. Vorlesungen über Ästhetik als allgemeine Wahrnehmungslehre. München: Wilhelm Fink. Japanese translation by Akira Imura, Masato Ogawa, Miyuki Abe, Yuichi Masuda. Tokyo: Keisoshobo.

Böhme, Gernot. 2006a. Architektur und Atmosphäre. München:Wilhelm Fink.

Böhme, Gernot. 2006b. The Aesthetics of Atmospheres - A challenge from New Phenomenology. Kyoto: Koyo Shobo. In Japanese

Böhme, Gernot. 1995. Atmosphäre. Essays zur Neuen Ästhetik. 6. ${ }^{\text {th }}$ ed. Frankfurt/M.: Suhrkamp

Böhme, Jacob. 1922. De signature rerum oder von der Geburt und Bezeichnung aller Wesen. In: Jacob Böhmes sämtliche Werke vol. 1. K.W., Schiebler (ed.). Leipzig: Johann Umbrosius Barth

Eckert, Nora. 1998. Das Bühnenbild im 20. Jahrhundert. Berlin: Henschel

Eco, Umberto. A Theory of Semiotics. Bloomington: Indiana University Press, 1976

Frank, Erich. 1962. Platon und die sogenannten Pythagoreer. Darmstadt: Wissenschaftliche Buchgesellschaft

Kümmerlen, Robert. 1929. Zur Aesthetik bühnenräumlicher Prinzipien. Ludwigsburg: Schmoll Lamb, Carl; Curtius, Ludwig. 1944. Die Tempel von Paestum. Leipzig: Insel-Verlag 
Larmann, Ralph. 2007. Stage Design, Köln: Daab

Schmitz, Hermann. 1999. Adolf Hitler in der Geschichte. Bonn: Bouvier.

Schuberth, Ottmar 1955. Das Bühnenbild. Geschichte, Gestalt, Technik. Munchen: Callwey

Tellenbach, Hubert. 1968. Geschmack und Atmosphäre. Salzburg: O. Müller

\section{NOTES}

1. For the Aesthetics of Atmospheres see my German and Japanese Books: Böhme 2001, 2005, 2006 a,b, 2009.

2. This article has been published in French in the proceedings of the 1st international congress on ambiances "Faire une ambiance, Grenoble, 2012". See Böhme 2011.

3. Cf. Böhme, 2004, Chapter III.2, "Theorie des Bildes".

4. See Eckert, 1998, esp. the chapter: "Mehr Licht! - Die Lichtbühne", p. 106-113.

5. Böhme, 2001, chapter IX.

\section{ABSTRACTS}

This article delineates the aesthetics of atmopheres in general but has an emphasis on making atmospheres. From this point of view the art of the stage set turns out to be a paradigm for what are the main concepts of the theory of atmosphere: types of atmospheres (characters), their quasi-objectivity, means to produce atmospheres, emotional content. The ubiquitous meaning of atmospheres is demonstrated from the background of staging everything in our present civilization: public events, politics, commodities, and even personal life.

Cet article dessine le contour d'une esthétique générale des ambiances (atmospheres) en mettant l'accent sur leur fabrication. De ce point de vue, l'art de la scénographie se révèle être un paradigme pour ce qui concerne les concepts principaux de la théorie des ambiances: les types d'ambiances (caractères), leur quasi-objectivité, les moyens pour produire une ambiance, le contenu émotionnel. La teneur ubiquitaire des ambiances est démontrée par la propension à tout scénographier dans notre civilisation présente : événements publics, politique, marchandises et même vie privée.

\section{INDEX}

Keywords: atmosphere, staging, commodity aesthetics, emotions, space

Mots-clés: ambiances, scénographie, esthétique, émotions, espace 


\section{AUTHOR}

\section{GERNOT BÖHME}

Prof. of Philosophy Technical Univ. of Darmstadt

Director of the Institut für Praxis der Philosophie

Institut für Praxis der Philosophie e.V., IPPh. Rosenhöhweg 25, D-64287 Darmstadt, FRG

re.boehme@t-online.de

www.ipph-darmstadt.de 